\title{
Value of hydroalcoholic treatment of rapeseed for oil extraction and protein enrichment ${ }^{\text {is }}$
}

\author{
Morgane Citeau ${ }^{1, *}$, Jennifer Regis ${ }^{2}$, Patrick Carré ${ }^{1}$ and Frédéric Fine ${ }^{3}$ \\ 1 OLEAD, 11 rue Gaspard Monge, 33600 Pessac, France \\ 2 SAS Pivert, Parc technologique des rives de l'Oise, Rue les rives de l'Oise, 60280 Venette, France \\ 3 Terres Inovia, 11 rue Gaspard Monge, 33600 Pessac, France
}

\begin{abstract}
This study investigated alternative solvents: ethanol and isopropanol, to replace hexane and enhance the quality and value of oil and meal. Rapeseed oil extraction was carried out using ethanol ( $92 \mathrm{wt} . \%$ or $96 \mathrm{wt.} \%$ ), isopropanol ( $84 \mathrm{wt} . \%$ or $88 \mathrm{wt.} \%$ ) or hexane (as reference). Results show that hydroalcoholic extraction increased meal protein content by $13 \%$ compared to hexane extraction, but without significant influence of alcohol and water content. However, increasing water content improved glucosinolate extractability. Isopropanol $84 \mathrm{wt} . \%$ eliminated most glucosinolates from the seeds, decreasing glucosinolate concentration by $49-73 \%$ compared to meals extracted by the other alcohols.
\end{abstract}

Keywords: hexane / ethanol / isopropanol / rapeseed meal quality

\begin{abstract}
Résumé - Intérêt des solvants hydro-alcooliques pour l'extraction de l'huile et l'enrichissement en protéines du tourteau de colza. L'étude a porté sur l'expérimentation de solvants alternatifs à l'hexane : éthanol et isopropanol à différents degrés d'alcool, visant à la fois une bonne capacité d'extraction de l'huile et l'amélioration de la qualité du tourteau grâce à l'augmentation de la concentration en protéines et à l'élimination de composants antinutritionnels type glucosinolates. L'extraction du colza a été réalisée par de l'éthanol à $92 \% \mathrm{~m} / \mathrm{m}$ et $96 \% \mathrm{~m} / \mathrm{m}$ d'alcool, de l'isopropanol à $84 \% \mathrm{~m} / \mathrm{m}$ et $88 \% \mathrm{~m} / \mathrm{m}$ d'alcool ou de l'hexane (solvant de référence). L'extraction hydro-alcoolique a augmenté la teneur en protéines du tourteau de $13 \%$ par rapport à l'extraction hexane, mais sans influence significativement de la nature de l'alcool ou de sa teneur en eau. L'augmentation de la teneur en eau du solvant a par contre augmenté l'élimination des glucosinolates. En particulier, l'isopropanol $84 \% \mathrm{~m} / \mathrm{m}$ a été le plus efficace, permettant de diminuer la teneur en glucosinolates du tourteau de $49-73 \%$ par rapport aux autres alcools.
\end{abstract}

Mots clés : hexane / éthanol / isopropanol / qualité du tourteau

\section{Introduction}

Vegetable protein production and use is a major agrifoodsector challenge for the future. On one hand, the everincreasing global demand for animal proteins is driving codemand for vegetable proteins as animal feed. On the other hand, the vegetable protein market for human consumption is booming, bringing with it a number of imperatives in terms of functional and nutritional quality.

Rapeseed meal is a source of protein, characterized by a well-balanced amino acid composition that offers potentially excellent nutritional value (Campbell et al., 2016). Rapeseed

\footnotetext{
Contribution to the Topical Issue "Rapeseed / Colza"

*Correspondence: m.citeau@olead.fr
}

meal comes from the oilseed crushing industry, where it is the main co-product, accounting for around $55 \%$ of rapeseed mass. After oil extraction, the rapeseed meal contains around 35$40 \%$ proteins, plus carbohydrates $(30-35 \%)$, crude fiber ( 10 $15 \%$ ), minerals $(5-10 \%)$, and up to $10 \%$ secondary plant metabolites (von der Haal et al., 2014; Carré et al., 2016). However, the current rapeseed oil production-line configurations limit the production of a digestible protein-rich meal (Grala et al., 1994; Adem et al., 2014; Mosenthin et al., 2016). The presence of anti-nutritional components (fibers, glucosinolates, phytates and phenolics) and the loss of protein solubility during the crushing process hinders further value recovery (Bell, 1993; Quinsac et al., 1994; Adem et al., 2014). Rapeseed meal is used as animal feed, mostly for cattle and pigs, but it is less suitable for poultry or fish. Rapeseed meal is 
currently the world's second-leading source of vegetable protein, way behind soybean.

Increasing concerns for health, safety and environmental care have prompted to study alternative solvents in order to substitute hexane in oil extraction (Li et al., 2014; Sicaire et al., 2015; Baümler et al., 2016; Breil et al., 2017). Sicaire et al. (2015) and Breil et al. (2017) used physical properties of solvents (viscosity, boiling point, vaporization enthalpy and toxicity), theoretical solvent-lipids solubility and extraction experimentations in order to compare different solvents. They demonstrated that extraction efficiency varies depending on the lipid class or component (TAG, phospholids, tocopherols...), and the solvent choice depends on lipids composition of the meal.

Also, regarding the principles of Green Chemistry and Green Extraction (Chemat et al., 2012), isopropanol and ethanol have many benefits as compared to other solvents. They are less toxic than other "green" solvents (Chemat et al., 2012; Prat et al., 2016), already authorized for food extraction by the European Directive 2009/32/EC, readily available and bio-sourced (Breil et al., 2017; Perrier et al., 2017). In term of energy, alcohols are not favorable in the conventional extraction process because of the energy required to evaporate solvent. However, extraction process can be adapted to the use of these solvents. For example, the distillation step of miscella can be replaced by cold demixing method to recover oil and solvent phase. This contributes to save energy and to lead to a more economically viable process (Carré et al., 2018).

Isopropanol and ethanol are made more polar solvents than hexane, which has negative consequences on oil selectivity and miscibility (Sicaire et al., 2015; Breil et al., 2017). However, they are known to simultaneously solubilize oil and some nonlipid components of seeds, which helps to concentrate the proteins and detoxify the meal. According to Berot and Briffaud (1983), the extraction of de-hulled rapeseed flour by ethanol or isopropanol at $60 \mathrm{v} / \mathrm{v} \%$ alcohol increased protein concentration from 53 to $61-63 \mathrm{~g}$ per $100 \mathrm{~g}$ of de-oiled dry matter and removed of $96-97 \%$ of polyphenols and more than $99 \%$ of glucosinolates, but not phytin phosphorus. Sinichi and Diosady (2014) used absolute isopropanol to extract de-hulled mustard seed, and showed that the extracted crude oil contained $15 \%$ of non-lipid dry matter with $12.8 \mathrm{~g}$ of carbohydrates and $2.2 \mathrm{~g}$ of nitrogenous matter per $100 \mathrm{~g}$ of dry crude oil. It could be deduced that the extraction yield of non-lipid components was around $6 \%$ of the initial mass of dry flour in the tested conditions.

Furthermore, studies have shown that the extraction efficiency of ethanol and isopropanol is hugely dependent on solvent water content and temperature. Thus, increasing water content in the solvent enhances the extraction of nonlipid components but reduces the efficiency of oil extraction. Fauduet et al. (1995) studied the influence of ethanol-water mixtures on the extraction of glucosinolates from rapeseed meal and showed that increasing water content in the solvent increased glucosinolates extraction yield: $94 \%, 40 \%$ and $14 \%$ of glucosinolates were removed by pure water, ethanol at $80 \mathrm{wt} . \%$ and ethanol at $97 \mathrm{wt} . \%$ alcohol, respectively. However, the use of pure water led to a $23 \%$ loss of the initial mass of proteins. Similarly, van Megen (1983) reported that decreasing alcohol content in ethanol (from $85 \mathrm{wt} \%$ to 65 wt.\% alcohol) increased the extraction yields of glucosi-
Table 1. Rapeseed composition.

\begin{tabular}{lllll}
\hline Sample & $\begin{array}{l}\text { Moisture } \\
\text { content } \\
(\mathrm{g} / 100 \mathrm{~g})\end{array}$ & $\begin{array}{l}\text { Total oil } \\
\text { content } \\
(\mathrm{g} / 100 \mathrm{~g} \\
\text { dry matter })\end{array}$ & $\begin{array}{l}\text { Average } \\
\text { protein content } \\
(\mathrm{g} / 100 \mathrm{~g} \text { dry } \\
\text { matter })\end{array}$ & $\begin{array}{l}\text { Glucosinolate } \\
\text { content }(\mu \mathrm{mol} / \mathrm{g} \\
\text { dry matter })\end{array}$ \\
\hline Rapeseed & 4.8 & 49.5 & 19.2 & 17.2 \\
\hline
\end{tabular}

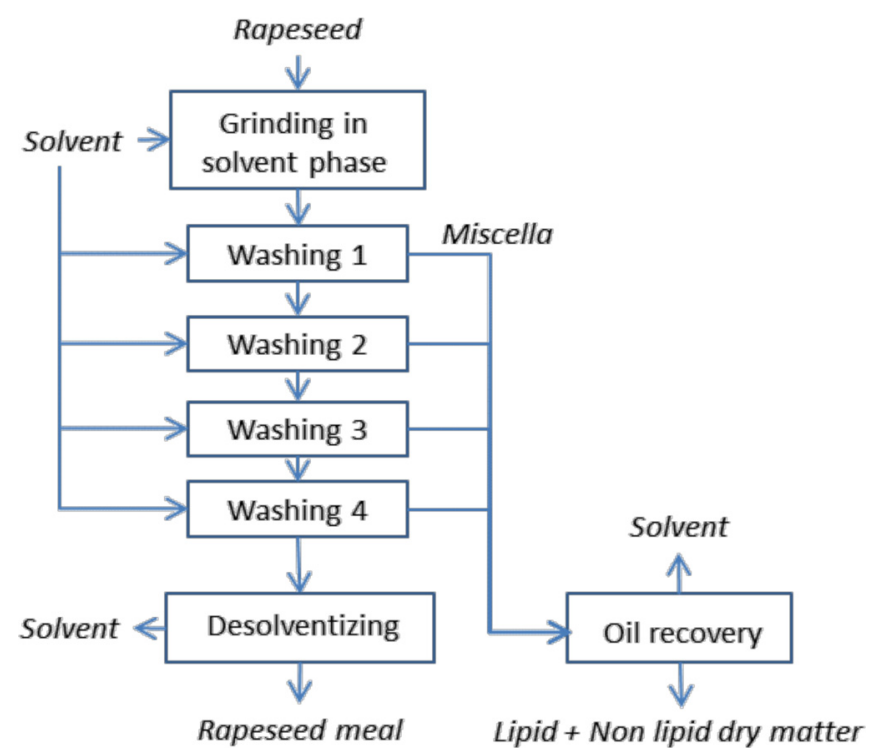

Fig. 1. Solvent extraction procedure.

nolates (from 49 to $92 \%$ at $60{ }^{\circ} \mathrm{C}$ ) and dry matter (from 21 to $27 \%$ at $\left.60{ }^{\circ} \mathrm{C}\right)$.

Studies to date have mainly tested hydroalcoholic solvents with high water content and dealt with pre-defatted matter to evaluate the ability of solvents to concentrate proteins in the meal and/or detoxify the meal. The aim of this study was to find a non-hexane solvent with good oil extraction capacity without losing non-lipid extraction efficiency. This study investigated the influence of solvent type, i.e. ethanol and isopropanol at various water contents, on oil extraction and rapeseed meal quality.

\section{Materials and methods}

\subsection{Materials}

Rapeseed was purchased from Alliance Occitane (Toulouse, France). Table 1 reports the rapeseed composition.

Hexane, ethanol and isopropanol were purchased from Quaron (Cestas, France) and were "technical” grade.

\subsection{Extraction procedure}

The process flow diagram in Figure 1 presents the rapeseed extraction procedure. The seeds were first crushed by a Silverson L5M-A high-shear laboratory mixer in the solvent phase $\left(4 \mathrm{~min}\right.$ at $8400 \mathrm{rpm}$ and $\left.15^{\circ} \mathrm{C}\right)$. The extraction experiments were then carried out in an agitated Nutsche filter (POPE 
a)

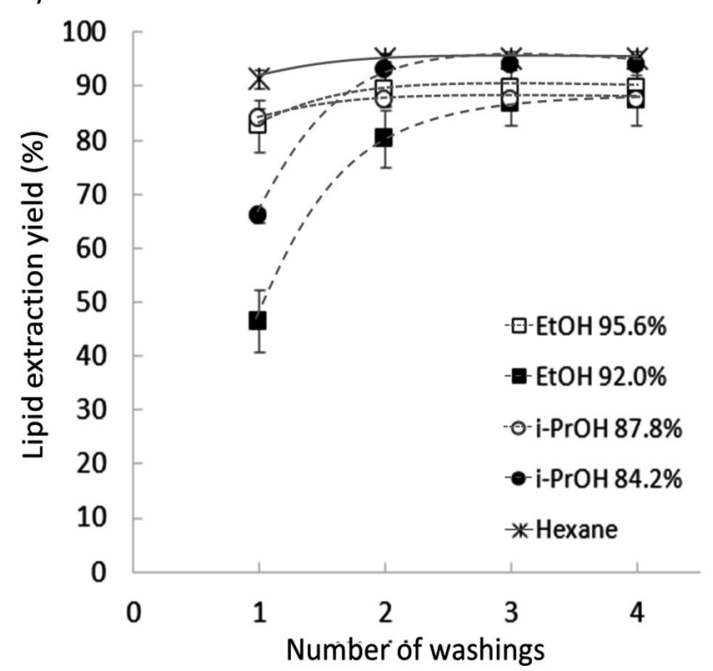

b)

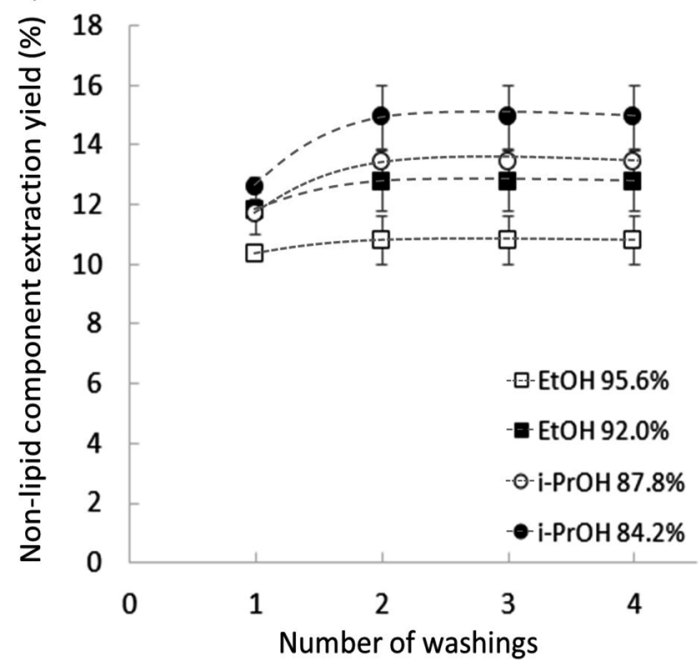

Fig. 2. Influence of solvent type and water content on a) lipid and b) non-lipid dry matter extraction yield in a 4-stage cross-current extraction. Error bars represent the standard deviation.

Scientific Inc., Saukville, WI) of total capacity $2.78 \mathrm{~L}$, equipped with a double jacket for temperature control, an agitator for mechanical stirring, and a stainless steel $20 \mu \mathrm{m}$ mesh (5 layers) on the bottom of the filter to separate the miscella from the solid after the desired extraction time. Fourstage cross-current extraction was performed by immersion of crushing seeds in preheated solvent (solvent/seed ratio: $1500 \mathrm{~g} /$ $100 \mathrm{~g}$ per stage; $10 \mathrm{~min}$ per stage, stirring at $42 \mathrm{rpm}$ and $50{ }^{\circ} \mathrm{C}$ ). Miscella was recovered by filtration after each washing step, and the miscella samples were used to measure the extracted matter or to analyze the proportion of lipid and non-lipid fractions in the extracted dry matter. Finally, the meal was exposed to ambient air to remove the solvent.

Isopropanol at $84.2 \mathrm{wt} . \%$ or $87.8 \mathrm{wt} . \%$ alcohol, ethanol at $92.0 \mathrm{wt} . \%$ or $95.6 \mathrm{wt} \%$ alcohol, and hexane (as reference) were tested as extraction solvents.

\subsection{Analysis}

\subsubsection{Analytical measurements}

Samples of miscella were desolventized in an oven $\left(103.5^{\circ} \mathrm{C}, 13 \mathrm{~h}\right)$ to measure dry matter content. Lipid and nonlipid contents of each miscella sample were determined by liquid-liquid extraction in hexane then water $(1: 1: 0.4 \mathrm{wt} / \mathrm{wt} / \mathrm{wt}$ miscella/hexane/water).

Total oil content of seeds and meals was determined according to NF v03-908. Total oil content of the meal is the sum of the extractable and non-extractable oil content. Extractable oil content was determined after Soxhlet extraction of the meal in hexane. Non-extractable oil content is the part of the residual oil content of the meal that is not readily extractable due to a seed grinding problem. It was quantified by a second grinding and extraction step run on the meal in hexane according to NF v03-908.

Moisture, protein and glucosinolate content of seeds and meals were determined according to ISO 771, ISO 5983-2 and ISO 10633-1, respectively. Protein solubility was determined by precipitation in potash according to ISO 14244. Protein and glucosinolate contents of seeds and meals were expressed on de-oiled dry matter basis using the following equation:

$$
C_{i}^{D D M}=\frac{C_{i}^{D M}}{1-C_{L}^{D M}},
$$

where $C_{i}^{D D M}$ is concentration of component $i$ (protein or glucosinolates) in the meal expressed on de-oiled dry matter basis (per mass of DDM), $C_{i}^{D M}$ is the concentration of the component $i$ expressed on a dry matter basis (per mass of DM) and determined by analysis, and $C_{L}^{D M}$ is total oil content in the meal determined by analysis $(\mathrm{g} / 100 \mathrm{~g}$ of $\mathrm{DM})$.

\subsubsection{Extraction yield}

Cumulated lipid and non-lipid dry matter extraction yields $\left(Y_{k}\right)$ were determined using the following equation:

$$
Y_{k}=\frac{\sum\left(C_{k}^{\mathrm{mis}} \times m^{\mathrm{mis}}\right)}{C_{k}^{\mathrm{seed}} \times m^{\mathrm{seed}}},
$$

where $m^{\text {seed }}$ is mass of seeds $(\mathrm{g}), m^{\text {mis }}$ is mass of miscella recovered at each washing step $(\mathrm{g}), C_{k}^{\text {seed }}$ and $C_{k}^{\text {mis }}$ are content of component $k$ (lipids or non-lipid dry matter) in the seeds and the miscella $(\%)$, respectively.

\subsubsection{Statistical analysis}

Experiments and analyses were repeated twice. To evaluate the effect of extraction conditions, data was submitted to analysis of variance (ANOVA, in Excel) with $p<0.05$.

\section{Results}

\subsection{Crude oil extraction yield}

Figure 2a reports lipid extraction yield after each washing step depending on type of solvent. The difference between 
Table 2. Composition of meals after 4 washings (solvent/matter ratio: $15 \mathrm{~g} / \mathrm{g}$, temperature: $50^{\circ} \mathrm{C}$ ).

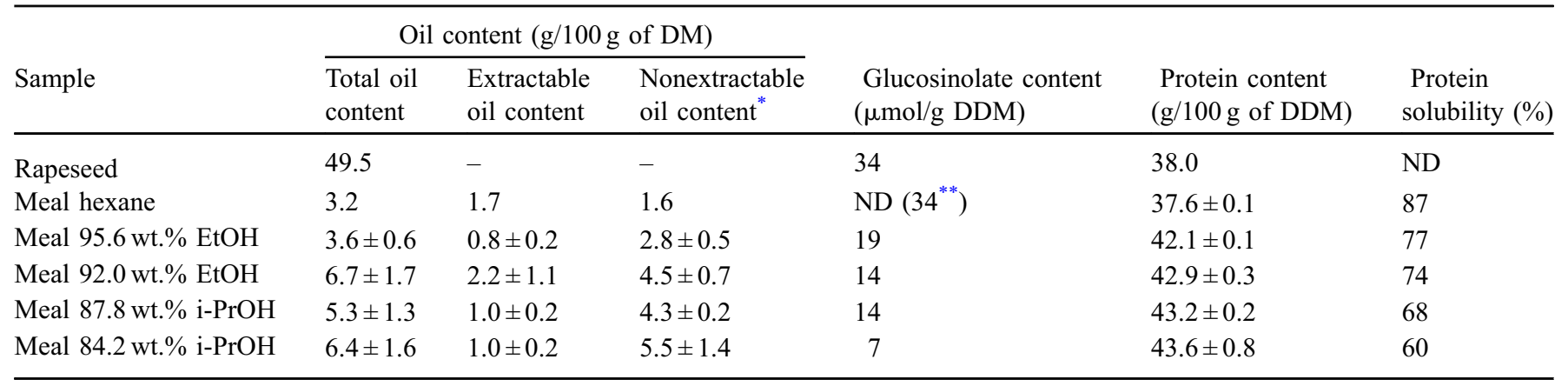

DM: dry matter basis; DDM: de-oiled dry matter basis; ND: not determined.

${ }^{*}$ Nonextractable oil content due to a seed grinding problem.

** Value estimated based on previous experiments.

solvents was mainly observed in the first wash: lipid solubility was reduced by the presence of water in alcohol, and hexane remained the most efficient solvent in terms of oil extraction. Lipid extraction yield thus reached $91 \%$ with hexane and $83-84 \%$ with azeotrope alcohols (95.6 wt.\% EtOH and $87.8 \mathrm{wt} . \%$ i-PrOH) at the first extraction step. A $3.6 \mathrm{wt} . \%$ increase in water content reduced lipid extraction yield to $46 \%$ and $66 \%$ for $92 \mathrm{wt} . \%$ EtOH and $84.2 \mathrm{wt} . \%$ i-PrOH, respectively. Consequently, as oil solubility decreased with alcohol content, the process required a higher quantity of solvent, and so a larger number of washings was required in order to extract the same amount of oil. The negative impact of the water content in alcohol on oil solubility was previously demonstrated by Rao and Arnold (1956 and 1957) for both ethanol and isopropanol and by Sinichi and Diosady (2014) for isopropanol. Nevertheless, as shown in Figure 2a, final yield, i.e. $(89.5 \pm 3.7)$ wt.\%, was not significantly impacted by the water content in the alcohol/water mixture $(p=0.298)$.

Furthermore, the variation in water content had less influence on lipid extraction by isopropanol than by ethanol. This result is in agreement with Rao and Arnold (1956, 1957) who demonstrated that the miscibility of vegetable oils was greater in isopropanol than in ethanol at a given water content.

Figure $2 \mathrm{~b}$ reports non-lipid dry matter extraction yield. Alcohols extracted some non-lipid components as previously reported (Berot and Briffaud, 1983; Sinichi and Diosady, 2014). The extracted non-lipid dry matter represented 11 to 15 wt. $\%$ of the initial defatted matter depending on water content. As observed, the higher the water content, the higher the extraction of non-lipid components. The maximum values of non-lipid dry matter yield were achieved after two washing steps. Note that non-lipid components were not extracted with hexane.

After alcoholic extraction and conventional distillation of the miscella, the crude oil contained $75-87 \%$ lipids and $12-$ $25 \%$ non-lipid compounds depending on solvent tested. These non-lipid compounds are impurities and will complicate oil recovery value. Recent results suggested that applying an oil recovery method by cooling the alcohol miscella instead of distillation leads to recovery of a non-lipid-compound-free oil, as the non-lipid compounds are retained in the solvent-rich phase (Oliveira et al., 2012; Citeau et al., 2018).

\subsection{Rapeseed meal quality}

Table 2 reports the composition of the meal after 4 extraction stages. Protein and glucosinolate concentrations were expressed on a de-oiled dry matter basis to compare results independently of the variation in residual oil content, particularly the oil content that was nonextractable due to a seed grinding problem.

The initial rapeseed contained $38 \mathrm{~g}$ of proteins per $100 \mathrm{~g}$ of de-oiled dry matter. The use of alcohol increased the protein concentration of the meal to around $42-44 \mathrm{~g} / 100 \mathrm{~g}$ without significant difference between alcohol types and water content $(p=0.087)$ but significantly higher than after hexane extraction $\left(p=1.64 \times 10^{-4}\right)$. Thus, the extraction of additional non-lipid compounds (estimated as $11-15 \mathrm{wt} . \%$ of the initial defatted matter) increased meal protein concentration by $11-16 \%$ compared to the hexane extraction meal. Berot and Briffaud (1983) demonstrated that protein concentration could reach $60 \mathrm{wt} . \%$ after ethanol or isopropanol extraction when using dehulled rapeseed. However, dehulling was not applied in the current study.

As shown in Table 2, alcohols removed glucosinolates from the meal, and the higher the water content, the lower the residual glucosinolates concentration, in agreement with Fauduet et al. (1995) and Van Megen (1983). Isopropanol 84.2 wt. \% eliminated the most glucosinolates from the oilseed, decreasing glucosinolate concentration by 49-73\% compared to meals extracted by the other alcohols.

Table 2 also shows that the use of alcohols reduced protein solubility. Note that the impact was greater with higher-watercontent solvent, in agreement with Sawada et al. (2014) who demonstrated that the protein solubility of soybean was decreased by the presence of water in ethanol and the loss of solubility was accentuated by increasing temperature. A loss of solubility reflects changes in protein conformation and a partial denaturation of the protein that could impact its functionality.

\section{Conclusion}

This study investigated the influence of solvent type, i.e. ethanol and isopropanol, at two water concentrations, on rapeseed extraction efficiency and rapeseed meal quality. Alcohol-based solvents extracted 11-15 wt.\% non-lipid 
matters along with the oil, thus increasing protein concentration to $42-43 \mathrm{~g}$ per $100 \mathrm{~g}$ of meal and decreasing glucosinolates concentration to $7-19 \mathrm{~g}$ per $100 \mathrm{~g}$ of meal depending on type of alcohol. In comparison, protein and glucosinolate concentrations were $38 \mathrm{~g}$ and $25 \mathrm{~g}$ per $100 \mathrm{~g}$ of meal, respectively, after extraction with hexane.

Lipid extraction was less affected by the variation of water content in isopropanol than in ethanol. In the tested conditions, the increase of water content did not affect the final protein concentration of the meal, but strongly affected protein denaturation and removal of glucosinolates. In particular, isopropanol with the highest water content eliminated the most glucosinolates from the oilseed, decreasing glucosinolate concentration by $49-73 \%$ compared to meals extracted by the other alcohols.

Acknowledgements. This work was performed in partnership with SAS PIVERT within the framework of the French Institute for Energy Transition - PIVERT Picardie Plant Innovations Teaching and Technological Research (www.institut-pivert.com) platform selected as an Investment for the Future (Investissements d'Avenir). This work received French government support (reference ANR-001-01) under the Investments for the Future program.

\section{References}

Adem HN, Tressel RP, Pudel F, Slawski H, Schulz C. 2014. Rapeseed use in aquaculture. OCL 21(1): D105.

Baümler ER, Carrín ME, Carelli AA. 2016. Extraction of sunflower oil using ethanol as solvent. J Food Eng 178: 190-197.

Bell JM. 1993. Factors affecting the nutritional value of canola meal: a review. Can J Anim Sci 73: 679-697.

Berot S, Briffaud J. 1983. Parameters for obtaining concentrates from rapeseed and sunflower meal. Plant Foods Hum Nutr 33: 237-242.

Breil C, Vian M, Zemb T, Kunz W, Chemat F. 2017. "Bligh and Dyer" and Folch methods for solid-liquid-liquid extraction of lipids from microorganisms. Comprehension of solvatation mechanisms and towards substitution with alternative solvents. Int JMol Sci 18: 708.

Campbell L, Rempel CB, Wanasundara JPD. 2016. Canola/rapeseed protein: Future opportunities and directions - Workshop Proceedings of IRC 2015. Plants (Basel) 5: 17.

Carré P, Citeau M, Robin G, Estorges M. 2016. Hull content and chemical composition of whole seeds, hulls and germs in cultivars of rapeseed (Brassica napus). OCL 23(3): A302.

Carré P, Citeau M, Dauguet S. 2018. Hot ethanol extraction: economic feasibility of a new and green process. OCL 25(2): D206.

Chemat F, Albert Vian M, Cravotto G. 2012. Green extraction of natural products: Concept and principles. Int J Mol Sci 13: 86158627.

Citeau M, Albe Slabi S, Joffre F, Carré P. 2018. Improved rapeseed oil extraction yield and quality via cold separation of ethanol miscella. OCL 25(2): D207.
Fauduet H, Coic JP, Lessire M, Quinsac A, Ribaillier D, Rollin P. 1995. Rapeseed meal upgrading-pilot scale preparation of rapeseed meal materials with high or low glucosinolate contents. Anim Feed Sci Tech 56: 99-109.

Grala W, Pastuszewska B, Smulikowska S, Buraczewska L, Gdala J. 1994. Effect of thermal processing on the protein value of doublelow rapeseed products 2 . Effect of processing stages in the oil plant and of toasting in laboratory conditions. J Anim Feed Sci 3: 43-55.

Li Y, Fine F, Fabiano-Tixier AS, et al. 2014. Evaluation of alternative solvents for improvement of oil extraction from rapeseeds. Comptes Rendus Chim 17(3): 242-251.

Mosenthin R, Messerschmidt U, Sauer N, Carré P, Quinsac A, Schöne F. 2016. Effect of the desolventizing/toasting process on chemical composition and protein quality of rapeseed meal. J Anim Sci Biotechnol 7: 36.

Oliveira CM, Garavazo BR, Rodrigues CEC. 2012. Liquid-liquid equilibria for systems composed of rice bran oil and alcohol-rich solvents: Application to extraction and deacidification of oil. J Food Eng 110: 418-427.

Perrier A, Delsart C, Boussetta N, Grimi N, Citeau M, Vorobiev E. 2017. Effect of ultrasound and green solvents addition on the oil extraction efficiency from rapeseed flakes. Ultrason Sonochem 39: 58-65.

Prat D, Wells A, Hayler J, et al. 2016. CHEM21 selection guide of classical- and less classical-solvents. Green Chem 18(1): 288-296.

Quinsac A, Lessire M, Krouti M, et al. 1994. Improvement in the nutritive value of high and low glucosinolate rapeseed meal by aqueous extraction. Anim Feed Sci Technol 48: 265-272.

Rao RK, Arnold LK. 1956. Alcoholic extraction of vegetable oils: III Solubilities of babassu, coconut, olive, palm, rapeseed, and sunflower seed oils in aqueous ethanol. J Am Oil Chem Soc 33: 389-391.

Rao RK, Arnold LK. 1957. Alcoholic extraction of vegetable oils. IV. Solubilities of vegetable oils in aqueous 2-propanol. $J$ Am oil Chem Soc 34(8): 401-404.

Sawada MM, Venâncio LL, Toda TA, Rodrigues CEC. 2014. Effects of different alcoholic extraction conditions on soybean oil yield, fatty acid composition and protein solubility of defatted meal. Food Res Int 62: 662-670.

Sicaire AG, Vian M, Fine F, et al. 2015. Alternative bio-based solvent for extraction of fat and oils: Solubility prediction, global yield, extraction kinetics, chemical composition and cost of manufacturing. Int J Mol Sci 16: 8430-8453.

Sinichi, S, Diosady LL. 2014. Isopropyl alcohol extraction of de-hulled yellow mustard flour. J Am Oil Chem Soc 91: 21432153.

van Megen WH. 1983. Removal of glucosinolates from defatted rapeseed meal by extraction with aqueous ethanol. Can Inst Food Sci Technol J 16: 093-096.

von der Haar D, Müller K, Bader-Mittermaier S, Eisner P. 2014. Rapeseed proteins - Production methods and possible application ranges. OCL 21(1): D104.

Cite this article as: Citeau M, Regis J, Carré P, Fine F. 2019. Value of hydroalcoholic treatment of rapeseed for oil extraction and protein enrichment. OCL 26: 1. 